\title{
Activation of Murine Immune Cells upon Co-culture with Plasma-treated B16F10 Melanoma Cells
}

\author{
Katrin Rödder ${ }^{1}$, Juliane Moritz ${ }^{1}$, Vandana Miller ${ }^{1,2}$, Klaus-Dieter Weltmann ${ }^{1}$, \\ Hans-Robert Metelmann ${ }^{3}$, Rajesh Gandhirajan ${ }^{1}$ and Sander Bekeschus ${ }^{1, *}$ \\ 1 Centre for Innovation Competence (ZIK) plasmatis, Leibniz Institute for Plasma Science and \\ Technology (INP Greifswald), Felix-Hausdorff-Str.2, 17489 Greifswald, Germany; \\ katrin.roedder@inp-greifswald.de (K.R.); juliane.moritz@inp-greifswald.de (J.M.); \\ vmiller@coe.drexel.edu (V.M.); weltmann@inp-greifswald.de (K.-D.W.); \\ rajesh.gandhirajan@inp-greifswald.de (R.G.) \\ 2 Department of Microbiology and Immunology, Drexel University, 245 N. 15th Street, Philadelphia, \\ PA 19102, USA \\ 3 Department of Oral and Maxillofacial Surgery/Plastic Surgery, Greifswald University Medical Center, \\ Ferdinand-Sauerbruch-Str. DZ 7, 17475 Greifswald, Germany; metelmann@uni-greifswald.de \\ * Correspondence: sander.bekeschus@inp-greifswald.de; Tel.: +49-3834-554-3948
}

Received: 23 January 2019; Accepted: 12 February 2019; Published: 15 February 2019

\begin{abstract}
Recent advances in melanoma therapy increased median survival in patients. However, death rates are still high, motivating the need of novel avenues in melanoma treatment. Cold physical plasma expels a cocktail of reactive species that have been suggested for cancer treatment. High species concentrations can be used to exploit apoptotic redox signaling pathways in tumor cells. Moreover, an immune-stimulatory role of plasma treatment, as well as plasma-killed tumor cells, was recently proposed, but studies using primary immune cells are scarce. To this end, we investigated the role of plasma-treated murine B16F10 melanoma cells in modulating murine immune cells' activation and marker profile. Melanoma cells exposed to plasma showed reduced metabolic and migratory activity, and an increased release of danger signals (ATP, CXCL1). This led to an altered cytokine profile with interleukin-1 $\beta$ (IL-1 $\beta$ ) and CCL4 being significantly increased in plasma-treated mono- and co-cultures with immune cells. In T cells, plasma-treated melanoma cells induced extracellular signal-regulated Kinase (ERK) phosphorylation and increased CD28 expression, suggesting their activation. In monocytes, CD115 expression was elevated as a marker for activation. In summary, here we provide proof of concept that plasma-killed tumor cells are recognized immunologically, and that plasma exerts stimulating effects on immune cells alone.
\end{abstract}

Keywords: kINPen; lymphocytes; macrophages; plasma medicine; reactive species

\section{Introduction}

Melanoma incidence rapidly increased over the last decades [1], and malignant melanoma is the most lethal form of skin cancer today [2]. Complicating its clinical treatment, the heterogeneity of malignant melanoma challenges the design of effective anti-tumor therapies [3]. Gold standard approaches in treatment and palliation include surgery, radiation therapy, chemotherapy, electrochemotherapy, adoptive cell transfer strategies, and immunotherapy [4-7]. The outstanding success of immunotherapies awarded with the Nobel Prize for Medicine and Physiology 2018 has provided compelling clinical evidence that the immune system plays a critical role in tumor defense [8]. Research interest in oncology is therefore not only focused on whether tumor cells are eliminated by a given substance or therapy, but also whether they can be recognized by immune cells [9]. Moreover, plasma treatment itself can also exert effects on immune cells [10-12]. 
The concept of immunogenic cancer cell death (ICD) proposes stimulation of an immune response against apoptotic tumor cells in a living host [13]. Apoptotic tumor cells, exposing plasma membrane-localized or intracellular molecules (damage associated molecular patterns, DAMPs), recruit myeloid cells [14]. Internalizing apoptotic cells, myeloid cells are capable to cross-present processed antigens on MHC class I molecules to tumor specific T cells [15]. This process results in a pro-inflammatory immune response [16], inducing tumor specific $\mathrm{CD}^{+} \mathrm{T}$ cells potentially able to target melanoma cells [17]. Physical therapies in oncology have been shown to be potent ICD inducers, such as ionizing radiation, electrochemotherapy, and photodynamic therapy [18]. Another medical technology, cold physical plasma, was recently suggested for anti-melanoma therapy and danger signaling [19-21].

For medical purposes, cold physical plasma is a partially ionized gas operated at atmospheric pressure and body temperature [22]. It reacts with ambient air and generates RONS species leading to decreased melanoma cell activity and growth in vitro [23-25] and in vivo [26-28]. High species concentrations can be used to exploit apoptotic redox signaling pathways in tumor cells [29], and first cancer patients have benefited from plasma therapy [30]. Plasma treatment can act in concert with other drugs [31-33], and plasma-generated reactive species induce pro-immunogenic molecules on tumor cells, such as ecto-calreticulin (CRT) [34-36]. Although the release of this and other DAMP signals after plasma treatment in melanoma cells has been shown, evidence of immune cell activation in response to plasma-treated melanoma is scarce. We here performed co-cultures of plasma-treated murine melanoma cells with murine splenocytes consisting of myeloid as well as lymphoid cells. Plasma treatment decreased melanoma activity and increased release of danger signals. The cytokine profile as well as cellular activation markers and signaling pathways were investigated in immune cells to track a hypothesized perception of plasma-killed tumor cells by lymphocytes or phagocytes.

\section{Materials and Methods}

\subsection{Cell Culture and Preparation of Splenocytes}

Murine metastatic melanoma B16F10 cells were cultured in RPMI 1640 (PAN-Biotech, Germany) supplemented with $10 \%$ fetal bovine serum (FCS), $2 \%$ penicillin/streptomycin, and $1 \%$ glutamine (Sigma, Germany). A total of $2-4 \times 10^{4}$ cells were seeded in $1 \mathrm{ml}$ cell culture medium in cell-culture treated 24-well plates one day prior to experimentation and allowed to adhere overnight. Spleens of eleven mice were prepared across all experiments using mechanical force and a $40 \mu \mathrm{m}$ cell strainer (VWR, Germany) to obtain splenocytes suspension containing, for example, T cells and myeloid cells, including macrophages and dendritic cells (DCs). Cells were washed and red blood cells lysed with lysis buffer (BioLegend, USA) before washing and suspending splenocytes in fully supplemented culture medium. Sacrifice and tissue harvesting were performed in accordance with ethical standards.

\subsection{Plasma Treatment and Co-Culture}

Plasma treatment was performed using an atmospheric pressure non-thermal plasma released by the plasma jet kINPen (neoplas, Germany), which was shown to exert no mutagenic effects [37]. As feed gas, argon (99.9999\% pure; Air Liquide, France) was used with a gas flow rate of 3 standard liters per minute (slm). Plasma was generated with a sinusoidal voltage of $2-6 \mathrm{kV}_{\mathrm{pp}}$ with a frequency of $\sim 1 \mathrm{MHz}$. The plasma jet was operated for $30 \mathrm{~min}$ prior to experiments to reduce effects of residual tube humidity on the plasma species composition [38]. The melanoma cells and splenocytes, respectively, were treated directly in 24-well plates. The plasma treatment of one well did not "spill over" into an adjacent (e.g., control) well as determined via measuring deposition of oxidants in both the treated and adjacent untreated wells in preliminary experiments (data not shown). The cultured well plate was placed $20 \mathrm{~mm}$ distant from the jet nozzle. The distance from the nozzle does play an important role as outlined previously [38]. We adjusted the distance in a way that the jet is as close as possible to the treated solution without liquid spilling into the jet (due to vortexing of the solution by the gas 
flux) that would extinguish the plasma ignition. The evaporation of the liquid induced by the gas flow of the kINPen was compensated for using a pre-determined amount of double-distilled water (to maintain iso-osmotic conditions) as described before [10]. For co-culture experiments, 1-2 $\times 10^{6}$ splenocytes were added to each well one hour after plasma treatment of melanoma cells.

\subsection{Quantification of Cytokines, Chemokines, and ATP}

For quantification of 12 different murine cytokines or chemokines, bead-based multiplex analysis was performed according to the vendor's instructions (BioLegend). Supernatants were harvested $24 \mathrm{~h}$ (monocultures) or $4 \mathrm{~h}$ (trans-well co-culture) after plasma treatment, and stored at $-20{ }^{\circ} \mathrm{C}$ for one week until final analysis. In preliminary experiments, we could not observe a deteriorating effect on a single target due to storage, and any of such effect would apply as systemic error to all samples of the measurement, keeping the relative differences the same. Targets analyzed were interferon (IFN)- $\gamma$, interleukin (IL)-2, tumor growth factor (TGF)- $\beta$, tumor necrosis factor (TNF)- $\alpha$, CCL2 (MCP-1), CXCL9 (MIG), IL-10, IL-6, CCL4 (MIP-1 $\beta$ ), IL-4, IL-12p70, and IL-1 $\beta$. Bead fluorescence was quantified on a CytoFlex S flow cytometer (Beckman-Coulter, USA), and target concentration was quantified against a known standard supplied by the manufacturer at a given concentration. The mean fluorescence intensity of each dilution series of the standard aids in generating standard curves that allow the absolute quantification of each target investigated in the cell culture supernatant. For quantification of CXCL1 (KC) in supernatants $6 \mathrm{~h}$ after plasma treatment, enzyme-linked immunosorbent assay (ELISA) was used (BioLegend) according to the manufacturer's protocol. ATP was measured in supernatants $6 \mathrm{~h}$ after treatment using the ATP determination kit (Thermo Fisher Scientific) according to the manufacturer's protocol.

\subsection{Quantification of $\mathrm{H}_{2} \mathrm{O}_{2}$}

Quantification of total $\mathrm{H}_{2} \mathrm{O}_{2}$ concentrations was performed using Amplex UltraRed reagent (Thermo Fisher Scientific). The assay was performed in 96-well microplates (NUNC, Denmark) according to the manufacturers' protocol. Fluorescence was read using a microplate reader (Tecan, Switzerland) with appropriate filter settings $\left(\lambda_{\text {ex }} 535 \mathrm{~nm} \lambda_{\text {em }} 590 \mathrm{~nm}\right.$ ). $\mathrm{H}_{2} \mathrm{O}_{2}$ levels were quantified against a known standard (dilution series of chemically produced $\mathrm{H}_{2} \mathrm{O}_{2}$ by Sigma, Germany).

\subsection{Metabolic Activity}

Metabolic activity was assessed by measuring the reduction of non-fluorescent resazurin (Thermo Fisher Scientific; final concentration of $100 \mu \mathrm{M}$ ) to fluorescent resorufin after $4 \mathrm{~h}$ of incubation under cell culture conditions. In experiments using splenocytes, cells were incubated either with or without PMA (phorbol 12-myristate-13-acetate; Sigma, Germany) at a final concentration of $100 \mathrm{ng} / \mathrm{ml}$. Fluorescence was read using a microplate reader (Tecan, Switzerland) with appropriate filter settings $\left(\lambda_{\text {ex }} 535 \mathrm{~nm}\right.$ $\left.\lambda_{\text {em }} 590 \mathrm{~nm}\right)$.

\subsection{Scratch Assay}

The scratch assay is a method to measure cell migration in vitro. The methodical basis contains a "scratch" in a cellular grown monolayer, monitoring the cellular regrowth until closure of the scratch. Essentially, the cellular migration is imaged and quantified at different time points after the scratch [39]. B16F10 melanoma cells were seeded at $7.5 \times 10^{4}$ cells per well in 24-well plates, yielding a confluent monolayer the next day. Melanoma cells were exposed to plasma or were left untreated, prior to scratching the monolayer with a $200 \mu$ l pipette tip vertically across the center of the well. The resulting gap distance was imaged (Observer Z.1; Zeiss, Germany) and quantified (AxioVision 4.91 software; Zeiss) at $0 \mathrm{~h}$ and $24 \mathrm{~h}$. In between, cells were cultured under standard conditions. 


\subsection{Cell Surface Marker Expression}

Splenocytes were incubated with Fc-block (BioLegend) to block non-specific binding of antibodies. In some experiments, cells were incubated for $20 \mathrm{~min}$ with Fluo-3 (ThermoFisher Scientific). To assess subpopulations and activation marker, the following anti-murine monoclonal and fluorescently tagged antibodies were used: CD3 Alexa Fluor 700, CD11b PE-Dazzle, CD115 Brilliant Violet 421, CD43 APC, CD44 PE-Dazzle 594, CD4 PE-Cy 7, CD8a PerCP/Cy 5.5, CD28 APC, CD45R APC-Cy7, I-A/I-E Alexa Fluor 488, Ly-6C Alexa Fluor 700, CD68 PerCP/Cy 5.5, Ly-6G Brilliant Violet 510, FceRI $\alpha$ PE, CD86 PE-Cy7 (all BioLegend). For kinase activation assays, co-cultured splenocytes were fixed in methanol for $1 \mathrm{~h}$ at $-20{ }^{\circ} \mathrm{C}$, washed in PBS, and incubated for $20 \mathrm{~min}$ with monoclonal antibodies directed against murine phospho-Erk1/2 PerCP/eFluor 710 (eBioscience, Germany) and lineage markers. Multicolor flow cytometry data were analyzed with Kaluza 2.1.1 software (Beckman-Coulter).

\subsection{Statistical Analysis}

Statistical analysis was performed using prism 8.01 (GraphPad Software, USA). Mean and standard errors are given. Statistical significance was reported with asterisks (n.s. $p>0.05 ;{ }^{*} p<0.05$; $\left.{ }^{* *} p<0.01 ;{ }^{* * *} p<0.001\right)$.

\section{Results}

\subsection{Plasma-Deposited Oxidants Decreased Melanoma Cell Viability and Motility}

Cold physical plasma introduces oxidants into liquids surrounding cells, with hydrogen peroxide $\left(\mathrm{H}_{2} \mathrm{O}_{2}\right)$ being among the long-lasting products of redox chemistry [40]. In pure PBS (Figure 1a) and fully supplemented cell culture medium (Figure 1b), $\mathrm{H}_{2} \mathrm{O}_{2}$ accumulated in a dose-dependent manner, validating the introduction of plasma-derived species in culture systems. The concentration of $\mathrm{H}_{2} \mathrm{O}_{2}$ differed only modestly between complex cell culture medium compared to buffered saline (PBS), suggesting that FCS in cell culture medium has a negligible effect on $\mathrm{H}_{2} \mathrm{O}_{2}$ pre-cursor species from the kINPen. Furthermore, the effect of FCS as a growth factor for B16F10 was measured via metabolic activity using different FCS concentrations. As expected, the melanoma cell metabolic activity increased with increasing FCS concentration (Figure 1c). Following this, the effect of plasma treatment on melanoma growth with and without FCS was analyzed and not found to be substantially different at $4 \mathrm{~h}$ (Figure 1d). This suggests a growth-supporting but not a dramatic antioxidative effect caused by the proteins of FCS with plasma treatment. To see whether FCS presence or absence during plasma treatment affects the migratory capability in melanoma cells, scratch assays were performed (Figure 1e). Results showed that the presence FCS had only a minor impact on cellular migration, in contrast to plasma treatment, which reduced cell regrowth with increasing treatment times (Figure 1f). Importantly, FCS-containing medium was added after treatment to both conditions to focus on short-term effects following plasma treatment. This suggests that within our experimental system, FCS (composed of various proteins) in solution only played a minor role in mediating or protecting from plasma effects on tumor cells. Altogether, plasma treatment slowed melanoma cells' metabolic activity and motility, regardless of FCS presence or absence. 
a
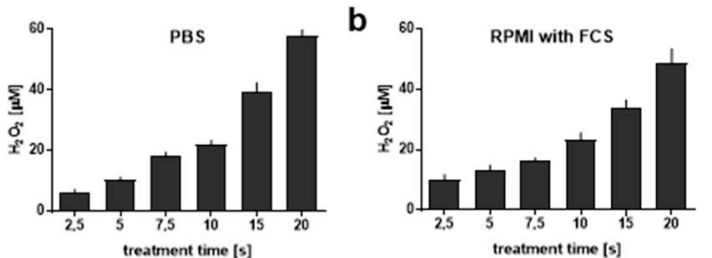

C

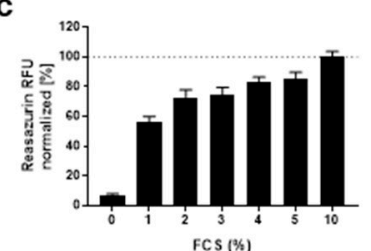

d

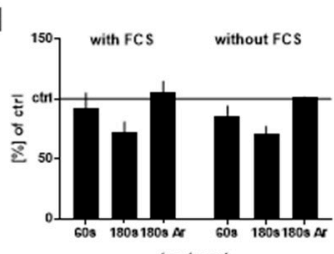

e
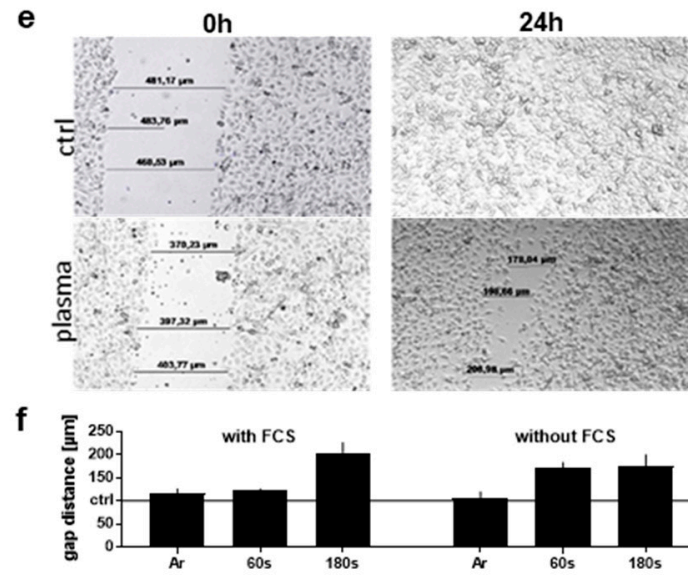

g

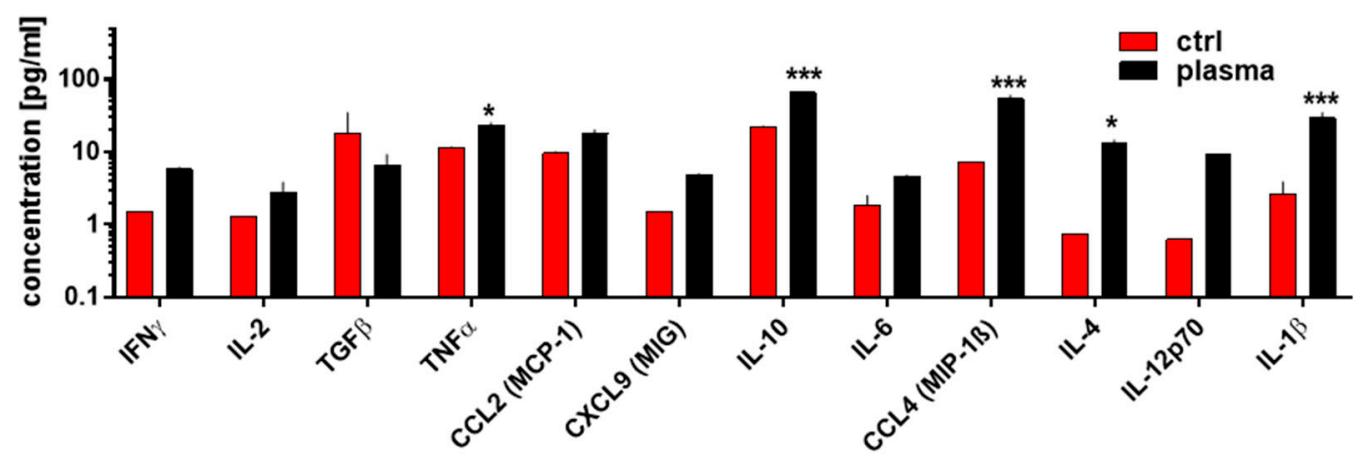

h
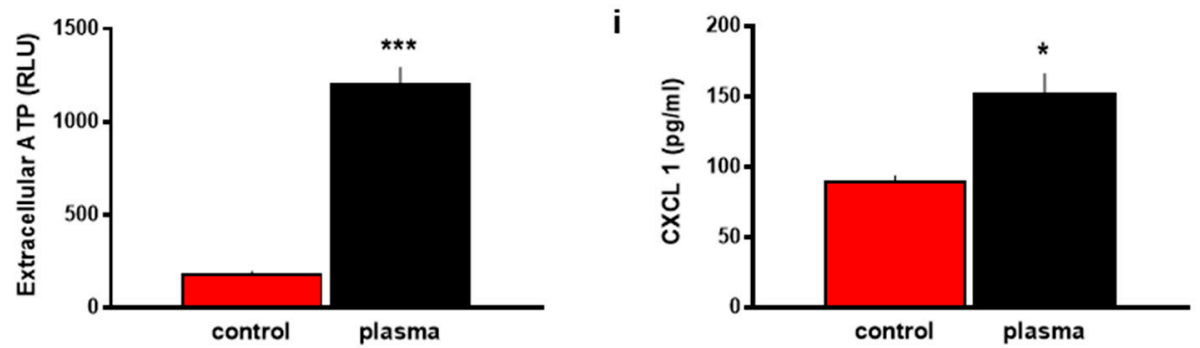

Figure 1. Effects of plasma treatment in liquids and treatment of B16F10 melanoma cells with physical plasma. (a) Plasma deposited hydrogen peroxide in PBS and (b) cell culture medium at nearly similar levels; (c) growth behavior of melanoma cells under different concentration of FCS; (d) reduction of metabolic activity in melanoma cells after plasma treatment in cell culture medium with or without FCS, normalization was done with respect to a control in each condition; (e) representative images of scratches in control or $180 \mathrm{~s}$ plasma-treated melanoma cells after $0 \mathrm{~h}$ or $24 \mathrm{~h}$, respectively, and (f) their normalized regrowth quantified; (g) cytokine/chemokine profile of plasma-treated melanoma cells; (h) release of the danger molecules ATP and (i) CXCL1 in plasma-treated melanoma cells. (a-d,f) Data are mean + S.E. from several replicates; statistical analysis was performed using t-test; PBS: phosphate-buffered saline; FCS: fetal calf serum.

\subsection{Plasma Treatment Modulated Inflammatory Milieu of Melanoma and Immune Cells}

In response to $120 \mathrm{~s}$ plasma treatment, melanoma cell supernatants (analyzed after $24 \mathrm{~h}$ ) showed significantly increased levels of TNF $\alpha$, IL-10, CCL4, and IL-1 $\beta$ compared to untreated control cells (Figure 1g). An increase of damage-associated molecules, such as ATP (Figure 1h) and CXCL1 (Figure 1i), was also observed $6 \mathrm{~h}$ after a $120 \mathrm{~s}$ plasma-treatment in B16F10 cells. Before investigating the immunological consequences of murine splenocytes co-cultured with plasma-treated melanoma 
cells, the response of splenocytes alone treated with plasma was investigated. For this, splenocytes were harvested from mice (Figure 2a) and left unstimulated or were pulsed with PMA. Lymphocyte activation is typically triggered by the interaction of the cell surface receptor to its specific ligand, resulting in an activation cascade. In vitro, lymphocyte activation can be induced by chemicals, such as PMA, leading to an increased cellular proliferation. Following this, splenocytes were exposed to plasma, and metabolic activity was assessed $24 \mathrm{~h}$ later. Reduced metabolic activity was observed in both naïve and PMA-stimulated splenocytes, but in the latter to a lesser extent (Figure 2b). Studying the splenocytes' supernatants, increased levels of cytokines were observed after plasma treatment, including IL-10, CCL4, IL-4, IL-12, and IL-1 $\beta$. Altogether, plasma treatment not only affected cell viability but also the inflammatory profile of tumor and immune cells (Figure 2c).

a

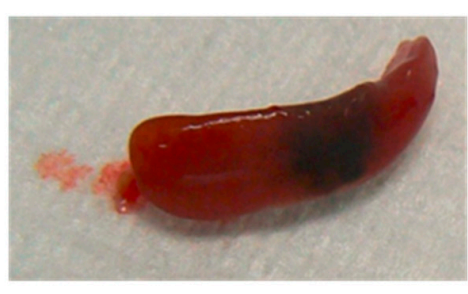

b

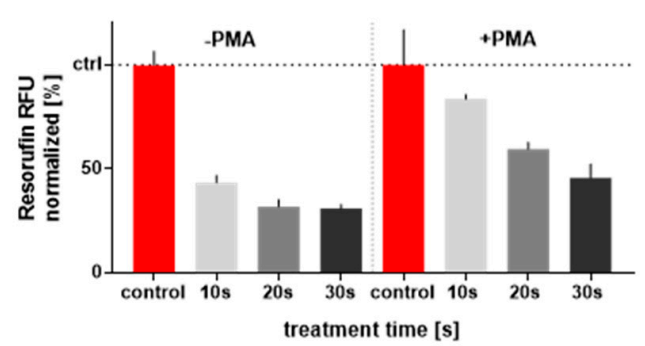

C

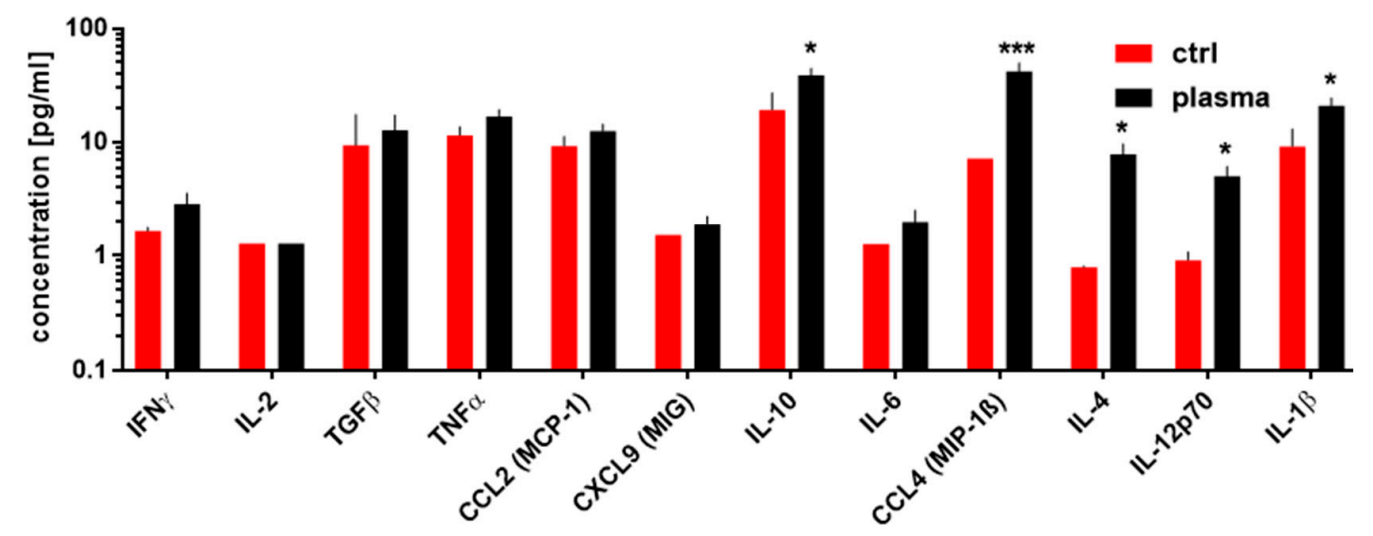

Figure 2. Treatment of murine immune cells with physical plasma. (a) Representative murine spleen after harvesting and prior to homogenization; (b) metabolic activity of naïve (-PMA) and activated (+PMA) splenocytes after plasma treatment; (c) cytokine/chemokine profile $24 \mathrm{~h}$ after $120 \mathrm{~s}$ plasma treatment in naïve splenocytes. Data are mean + S.E. of several spleens, statistical analysis was performed using $\mathrm{t}$ test. PMA: phorbol 12-myristate 13-acetate.

\subsection{Activation of Immune Cells with Plasma Treatment}

Cellular activation can be assessed using several methods such as calcium signaling. Fluo-3 is a labelled calcium indicator, and its fluorescence increases 100-fold upon calcium binding. Calcium influxes were observed in early lymphocyte activation. Total cellular fluorescence was measured by flow cytometry in macrophages (Figure 3a) and T cells (Figure 3b). After addition of Fluo-3 labeled splenocytes to plasma-treated melanoma cells, there was no significant change in calcium influx in macrophages (Figure 3c) and T cells (Figure 3d). Of note, a significant calcium influx was demonstrated for splenocytic $\mathrm{T}$ cells directly exposed to plasma and over time (Figure 3c) but not in macrophages (Figure 3d). Calcium release and protein kinase activity are closely linked. Being a member of the Ras-Raf-Erk signal transduction cascade, the Erk1/2 (extracellular signal-regulated Kinase-1/2) kinases are activated via phosphorylation. Upon activation, the Erk kinases function in cellular proliferation, differentiation, and survival. A significant increase (Figure 3e) of phosphorylated Erk1/2 was demonstrated for plasma-treated $\mathrm{T}$ cells after $1 \mathrm{~h}$ and $4 \mathrm{~h}$ (Figure 3f). For splenocytes 
co-cultured with plasma-treated B16F10 melanoma cells, a small but significant increase was observable $1 \mathrm{~h}$ after culture onset (Figure 3f). This suggests that plasma treatment and plasma-treated melanoma cells may be able to stimulate immune cells.

a

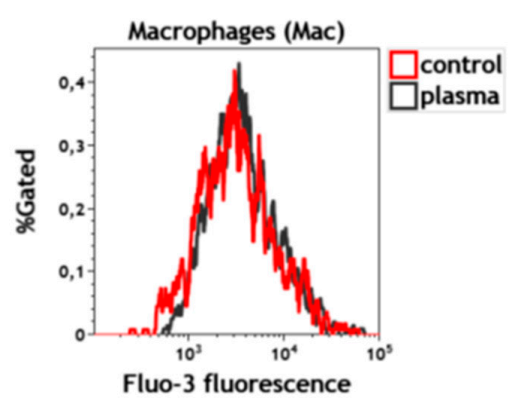

b

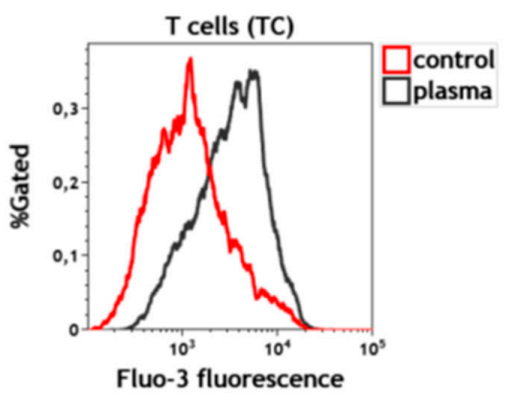

c
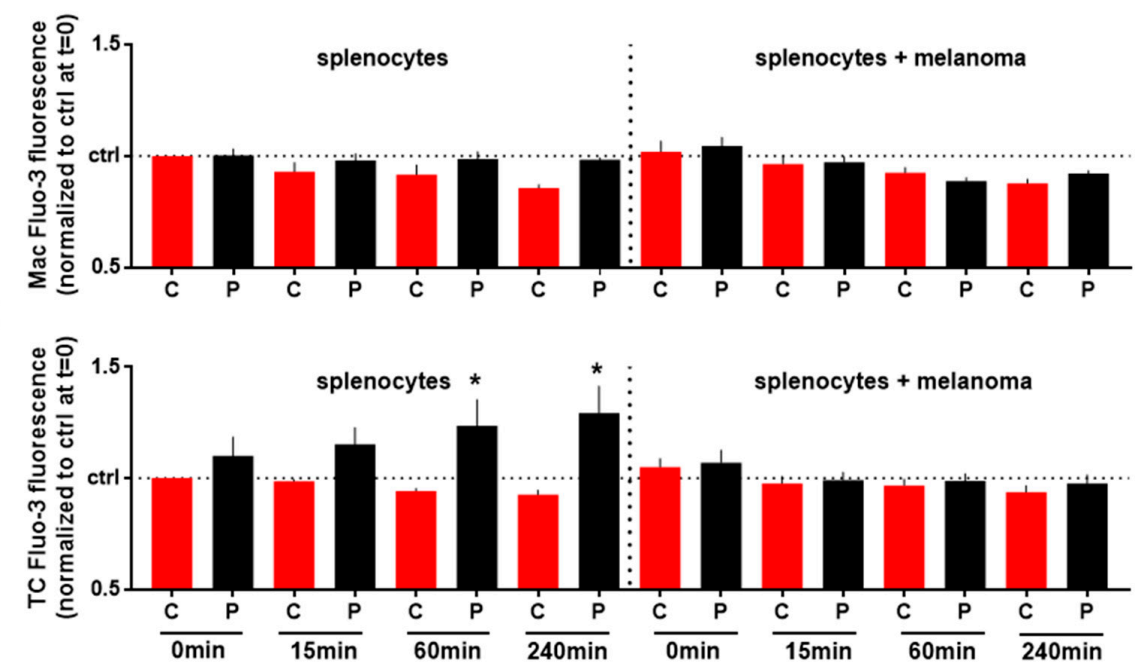

e

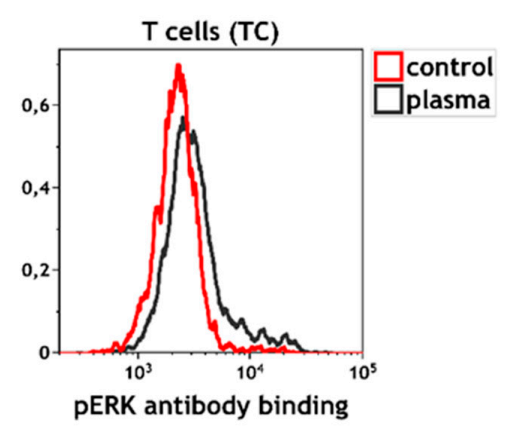

f

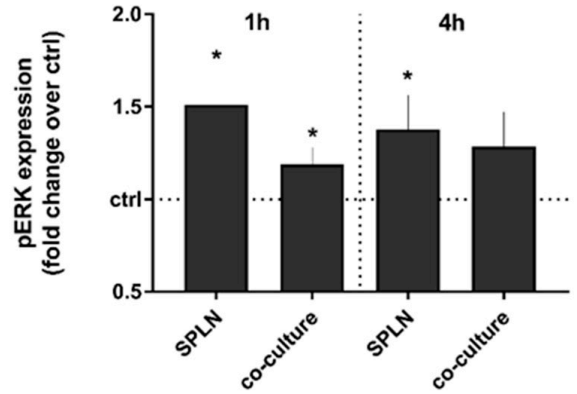

Figure 3. Activation of selected splenocyte subpopulations after co-cultivation with $120 \mathrm{~s}$ plasma-cells. (a) Representative overlay of calcium release assessed via flow cytometry in macrophages and (b) T cells, respectively; (c,d) quantification of calcium release over time in macrophages and $\mathrm{T}$ cells, respectively after plasma treatment (e) representative overlay of phosphorylated extracellular signal-regulated Kinase-1/2 (Erk1/2) kinase in T cells $1 \mathrm{~h}$ as measured via flow cytometry; (f) quantification of Erk1/2 phosphorylation in splenocytes with or without co-culture with $120 \mathrm{~s}$ plasma-treated melanoma cells after $1 \mathrm{~h}$ or $4 \mathrm{~h}$. Data are mean + S.E. of several spleens; $\mathrm{c}=$ control, $\mathrm{p}=\mathrm{plasma}, \mathrm{SPLN}=$ splenocytes. 


\subsection{Co-Culture with Plasma-Treated Melanoma Cells Altered the Surface Marker and Cytokine Profile of Murine Immune Cells}

Among splenocytes, $\mathrm{CD}^{+} \mathrm{T}$ helper and $\mathrm{CD} 8^{+}$cytotoxic $\mathrm{T}$ cells were identified from $\mathrm{CD}^{+}$ splenic lymphocytes (Figure 4a). With both lymphocyte subpopulations, the expression of the activation-indicating surface marker CD28 was assessed after co-culture with either untreated melanoma cells or plasma-treated melanoma cells (Figure 4b-c). CD28 expression on the cell surface increased in tendency for $\mathrm{CD}_{4}^{+}$and significantly for $\mathrm{CD} 8^{+} \mathrm{T}$ cells (Figure $4 \mathrm{~d}$ ). The CD28 cell surface marker provides essential co-stimulation during $\mathrm{T}$ cell activation. The expression of other activating $\mathrm{T}$ cell markers (CD44, CD152) did not change (data not shown). Only viable cells were included in the analysis, and we also investigated changes of the CD4/CD8 ratio. This parameter is used to describe the immune status, and we found an increase of CD4 over CD8 cells upon co-culture with plasma-treated over non-treated melanoma cells (Figure 4e). This suggests splenic CD4 ${ }^{+} \mathrm{T}$ helper cells survive better in the microenvironment generated by plasma-treated melanoma cells. To assess any changes of myeloid immune cells under these conditions, splenocytes were gated for monocytes and macrophages (Figure 5a). Several surface markers for M1 macrophages (CD115), M2 macrophages (FcER1), and co-stimulation during antigen presentation (CD86) were investigated (Figure 5b).

Monocytes had upregulated surface marker expression after co-culture with plasma-treated melanoma cells, with a significant increase of CD115, arguing for an onset of monocyte-to-macrophage maturation. Macrophages did not show any significant changes, with a non-significant decrease of CD86. Finally, cytokine analysis of splenocyte-melanoma trans-well co-cultures revealed increased levels of IL-10 and CCL4, with a trend of increased release with IL-1 $\beta$, IL-12p70, TNF $\alpha$, and TGF $\beta$ (Figure 5c). This argued for a modulation of the immune cells inflammatory response in when exposed to plasma-treated tumor cells.

\section{Discussion}

Our aim was to identify activation signatures in murine immune cells derived from spleen that had been co-cultured with plasma-treated melanoma cells. Although many responses observed in immune cells were rather subtle, their sum point to a principle recognition of plasma-treated compared to control melanoma cells.

Direct plasma treatment induced pro-inflammatory cytokine release of IL-1 $\beta$ or TNF- $\alpha$ in B16F10 melanoma cells. IL-1 $\beta$ is processed and released under caspase- 8 regulated apoptotic cell death [41]. Apoptotic cells release uric acid, activating systemic inflammation and resulting in release of IL-1 $\beta$ [42]. Interleukin- $1 \beta$ is a potent activator molecule in $\mathrm{T}$ and $\mathrm{B}$ cell responses and supports survival of naive and memory $\mathrm{T}$ cells [43-45], potentially forming anti-tumor immunity. Tumor necrosis factor alpha $(\mathrm{TNF} \alpha)$ leads to pyrogenic activation, inducing apoptotic cell death via the extrinsic pathway [46]. Plasma treatment of melanoma cells in mono and co-culture also increased release of IL-10 and CCL, both positively regulating $\mathrm{T}$ cell function [47]. Hence, plasma-derived oxidative cell stress and/or death of melanoma cells profoundly affected inflammatory conditioning of cells of the immune system. Presence of FCS during plasma treatment was of minor importance corroborating previous results that excess protein has negligible effects on plasma-derived long-lived oxidants [36]. Plasma-induced tumor cell death supposedly was of an immunogenic nature, as release of ATP and CXCL1 suggests [48], which is in line with earlier reports $[34,35,49,50]$.

In this study, immune cells derived from spleens were exposed to plasma. Similar to studies with human immune cells [51-53], splenocytes' viability was affected by direct exposure to plasma, while their mitogenic activation (with PMA) reduced plasma-mediated toxic effects. As the conditions (cell number, treatment time, volume of media, etc.) were the same in both non-activated and activated regimens but with different outcomes, our results point to differences in intracellular signal translation upon expose to reactive species, as these responses ultimately determines the amplitude of toxicity. At lower concentrations, reactive species can also serve in cell signaling [54]. 
Several studies manifested the role of ROS, in particular $\mathrm{H}_{2} \mathrm{O}_{2}$, as a stimulant and second messenger in lymphocytes [55]. An increase in intracellular calcium was found in plasma-treated $\mathrm{T}$ cells in our study, which points to their activation [56,57]. Elevated intracellular calcium levels need to be maintained for more than $30 \mathrm{~min}$ for $\mathrm{T}$ cell activation $[57,58]$, which was the case with our results. Moreover, we determined a significant increase in Erk1/2 activation in T cells, which is associated with activation $[59,60]$. In general, we do no propose a specific but rather non-specific stimulus of lymphocytes with plasma as this is highly unlikely without proper $\mathrm{T}$ cell receptor stimulation as previously described [22] and suggested experimentally [61,62]. Co-culture of splenocytes with plasma-treated melanoma cells provoked calcium influx neither in $\mathrm{T}$ cells nor in macrophages. For $\mathrm{T}$ cells, this suggests a lack of specific antigen being presented either on tumor (MHC I) or antigen presenting cells (MHC II). For macrophages, calcium signaling is often related to aberrant stress of the endoplasmic reticulum and cell death [63] or sensing of microorganisms [64].

Both $\mathrm{CD} 4^{+} \mathrm{T}$ helper and $\mathrm{CD} 8^{+}$cytotoxic $\mathrm{T}$ cells contribute to antitumor immunity in tumor patients [65-67]. $\mathrm{CD}^{+}$and $\mathrm{CD} 8^{+} \mathrm{T}$ cells co-cultured with plasma-treated compared to untreated melanoma cells showed an increased expression of CD28. When binding to its ligands (B7 receptors, e.g., CD80/86) triggering IL-2 release [68], the CD28 costimulatory receptor is required for efficient and optimal immune response in T lymphocytes [69]. CD28-signaling through Bcl-2 and Bcl-xL promotes T cell survival [70-72]. Importantly, basal CD28 expression in healthy volunteers, as well as in patients, correlates with a $\mathrm{T}$ cell phenotype more sensitive to stimulation, and low CD28 expression is a marker of disease [73]. Moreover, plasma treatment of splenocytes significantly increased levels of IL-4 and IL-12. The former induces $\mathrm{T}_{\mathrm{H}} 2$ and the latter $\mathrm{T}_{\mathrm{H}} 1$ responses, having opposite roles in health and disease [74]. Both cytokines are derived from myeloid cells such as basophils and monocytes/macrophages [75]. Although calcium increase was not observed in immune cells upon co-cultured with plasma-treated melanoma cells, an upregulation of surface marker was observed in monocytes in that condition. CD86 expression is induced upon stimulation in monocytes, leading to an inflammatory milieu [76] and proper T cell co-stimulation [77]. Increase of $\operatorname{IgE}$ receptor (FcER) dependent activation of monocytes is associated with tissue inflammation and cytotoxicity allergic diseases and asthma [78,79]. However, significantly regulated was only colony-stimulating factor 1 receptor (CSF-1R or CD115). CD115 contributes to macrophage maturation [80] and is crucial for the development of certain myeloid subsets as CD115 blockage shortens the life span of monocytes [81].

Several studies by others and us have observed plasma-induced tumor cell death before [82-98]. Kumar and colleagues observed in several pancreatic cancer cell lines an increase in apoptosis concomitant with downregulation of MAPK7, BCL2, and CHK1 [99]. In line with our results, they have observed an increase in $\mathrm{H}_{2} \mathrm{O}_{2}$ with plasma treatment using the kINPen, and moreover found apoptosis-inducing effects of plasma treatment in lung cancer cells based on increase in plasma-mediated ROS formation and intracellular oxidation signaled via ATM and p53 machinery [100], which is supported by our recent data in HaCaT keratinocytes [101]. 
a

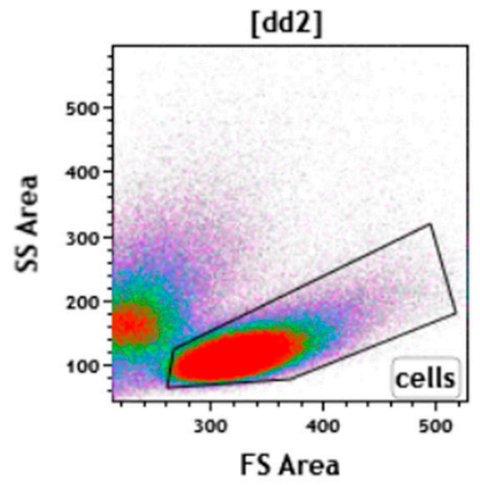

[cells]

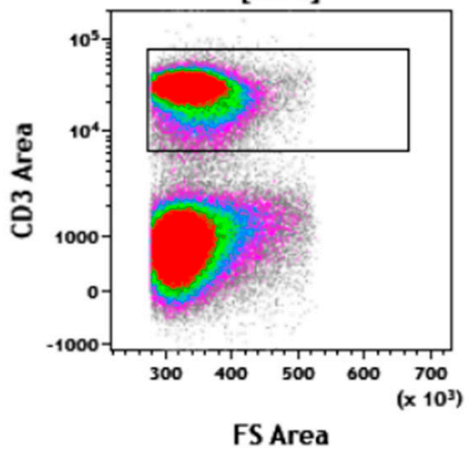

[CD3]

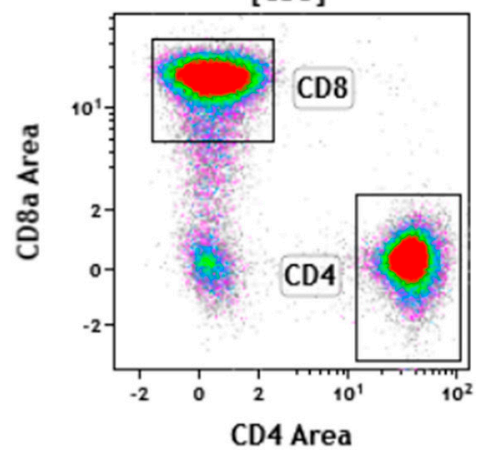

b

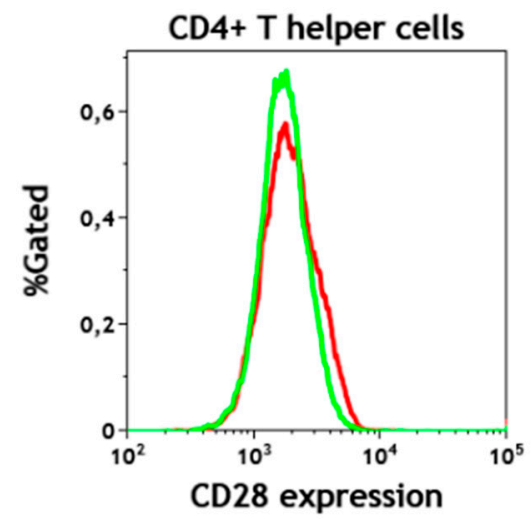

c CD8+ cytotoxic T cells

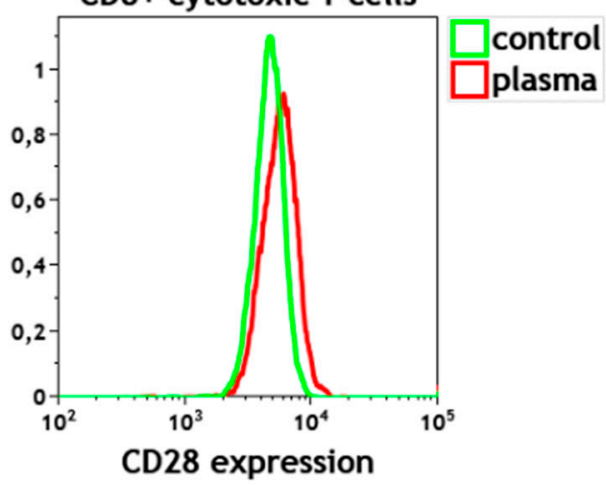

e
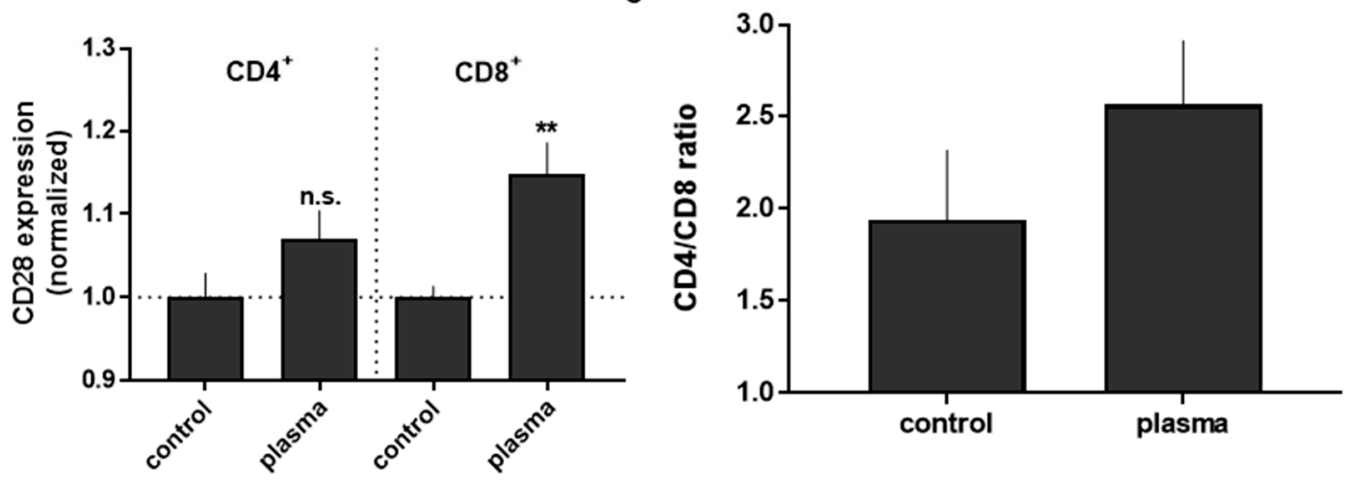

Figure 4. CD28 expression in T lymphocyte splenocyte subpopulations co-cultured with control or plasma-treated melanoma cells. (a) Representative flow cytometric dot plots used to gate for two $\mathrm{T}$ lymphocyte subpopulations, namely CD4+ T helper and CD8+ cytotoxic T cells; $(\mathbf{b}, \mathbf{c})$ representative overlay histograms for $\mathrm{CD} 28$ marker in expression in $\mathrm{CD} 4+$ and $\mathrm{CD} 8+$ cells, respectively; (d) fold change quantification of CD28 expression in T cells co-cultured for $24 \mathrm{~h}$ with either control or plasma-treated melanoma cells; (e) CD4/CD8 of T cells co-cultured for $24 \mathrm{~h}$ with either control or plasma-treated melanoma cells. Data are mean + S.E. of several spleens, statistical analysis was performed using $t$ test. 
a

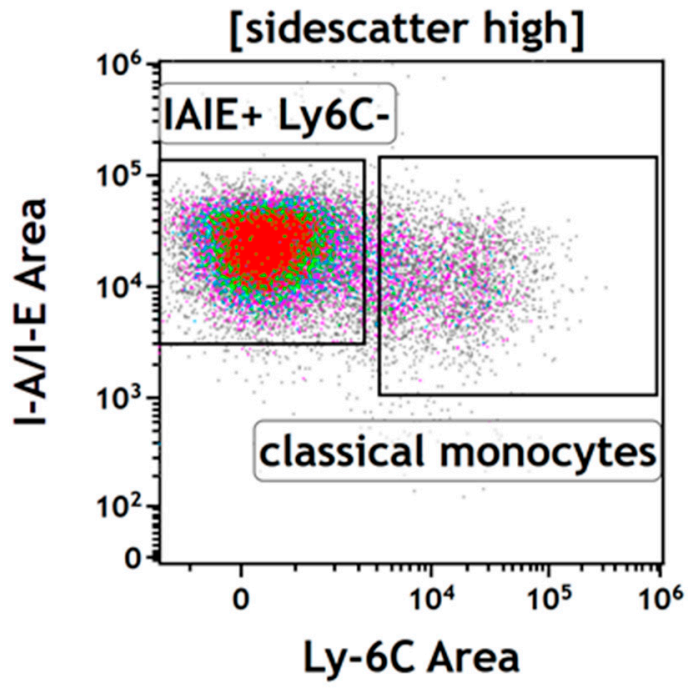

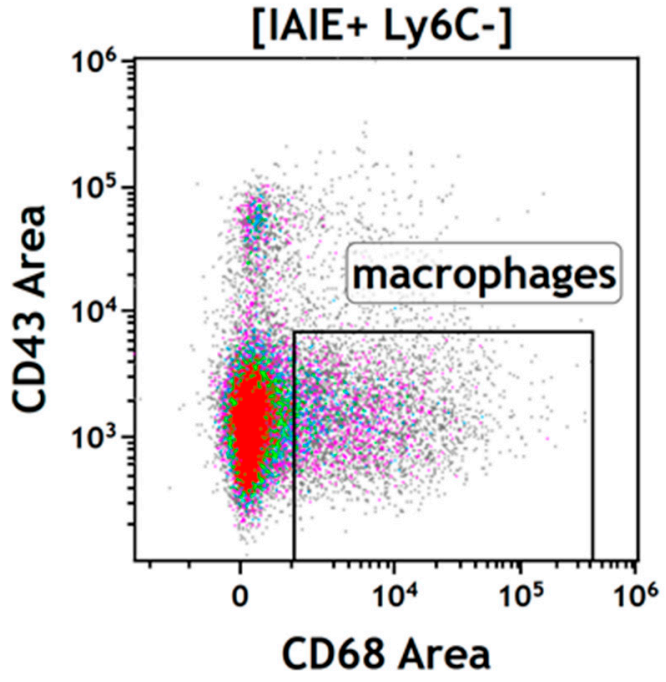

Macrophages

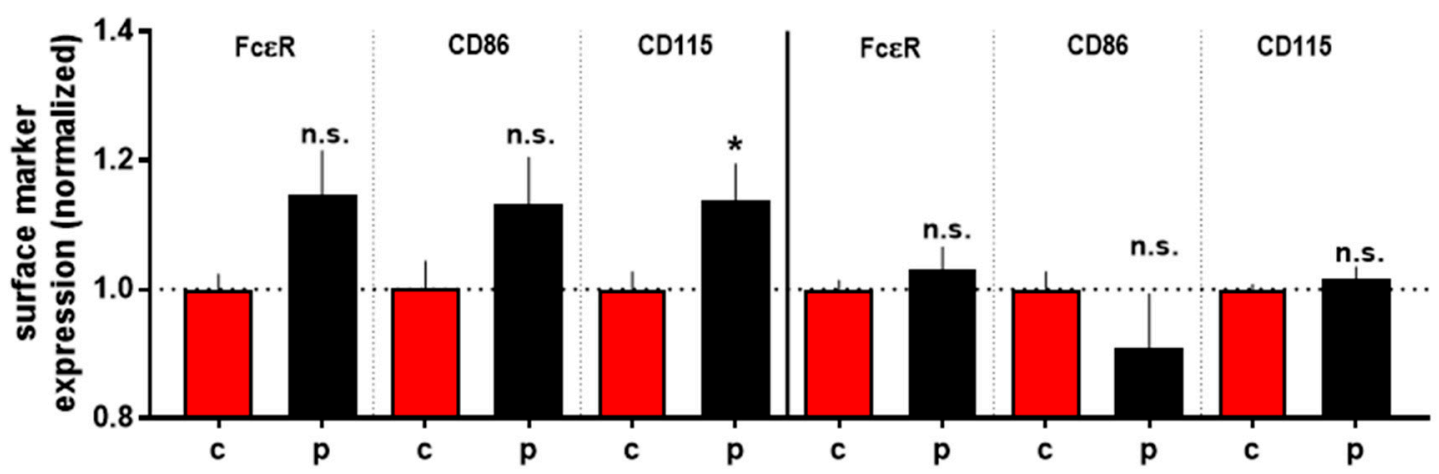

C

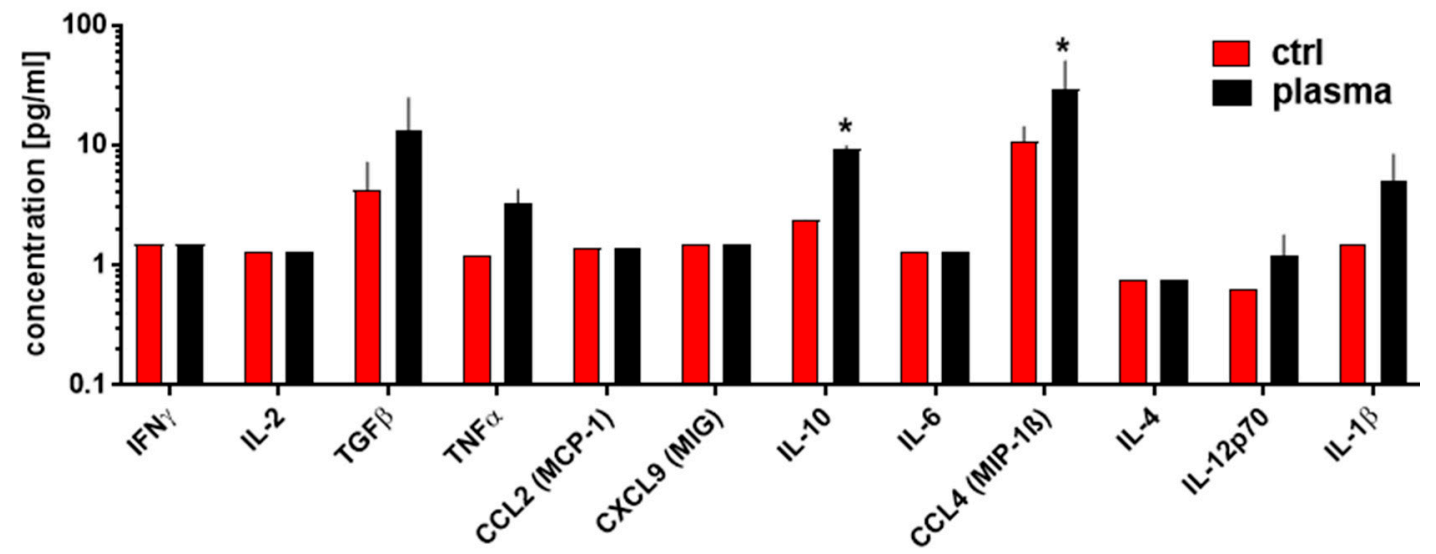

Figure 5. Activation of monocyte and macrophage splenocyte subpopulations after co-culture with melanoma cells. (a) Representative gating strategy to identify monocytes and macrophages within splenocytes; (b) of change expression of activation marker expression in monocytes/macrophages $24 \mathrm{~h}$ after co-culture with either control (C) or plasma-treated (P) melanoma cells; (c) cytokine profile supernatants retrieved from transwell co-cultures of control or plasma-treated melanoma cells with splenocytes. Data are presented as mean + S.E. of several spleens; statistical analysis was performed using $t$ test. 


\section{Conclusions}

Our findings indicate a tumor-static action in terms of metabolic activity and cell motility of plasma on melanoma cells and-in our hands-a negligible protective effect of protein present during the treatment. We further observed a role of plasma-mediated activation of splenic immune cells, as well as an effect of plasma-treated melanoma cells on immune cells. Specifically, plasma treatment modulated inflammatory parameters (such as cytokines and cell surface activation markers), which argue for pro-immunogenic role of plasma treatment. Additional studies with further differentiated assays and immune phenotyping are needed to understand how plasma technology can be used in onco-immunology to decrease tumor burden.

Author Contributions: Conceptualization, S.B. and V.M.; methodology, S.B., K.R., J.M. and R.G.; formal analysis, S.B., K.R., J.M. and R.G.; investigation, S.B., K.R. and J.M.; resources, S.B.; writing-original draft preparation, S.B.; writing-review and editing, S.B., V.M., K.-D.W. and H.-R.M.; supervision, S.B. and H.-R.M.; project administration, S.B.; funding acquisition, S.B. and K.-D.W.

Funding: This research was funded by the German Federal Ministry of Education and Research (BMBF), grant number 03Z22DN11.

Conflicts of Interest: The authors declare no conflict of interest.

\section{References}

1. Linos, E.; Swetter, S.M.; Cockburn, M.G.; Colditz, G.A.; Clarke, C.A. Increasing burden of melanoma in the United States. J. Investig. Dermatol. 2009, 129, 1666-1674. [CrossRef] [PubMed]

2. Erdei, E.; Torres, S.M. A new understanding in the epidemiology of melanoma. Expert Rev. Anticancer Ther. 2010, 10, 1811-1823. [CrossRef] [PubMed]

3. Bittner, M.; Meltzer, P.; Chen, Y.; Jiang, Y.; Seftor, E.; Hendrix, M.; Radmacher, M.; Simon, R.; Yakhini, Z.; Ben-Dor, A.; et al. Molecular classification of cutaneous malignant melanoma by gene expression profiling. Nature 2000, 406, 536-540. [CrossRef]

4. Bajetta, E.; Del Vecchio, M.; Bernard-Marty, C.; Vitali, M.; Buzzoni, R.; Rixe, O.; Nova, P.; Aglione, S.; Taillibert, S.; Khayat, D. Metastatic Melanoma: Chemotherapy; Elsevier: Amsterdam, The Netherlands, 2002; pp. 427-445.

5. Jandus, C.; Speiser, D.; Romero, P. Recent advances and hurdles in melanoma immunotherapy. Pigment Cell Melanoma Res. 2009, 22, 711-723. [CrossRef] [PubMed]

6. Queirolo, P.; Marincola, F.; Spagnolo, F. Electrochemotherapy for the management of melanoma skin metastasis: A review of the literature and possible combinations with immunotherapy. Arch. Dermatol. Res. 2014, 306, 521-526. [CrossRef] [PubMed]

7. Rosenberg, S.A.; Dudley, M.E. Adoptive cell therapy for the treatment of patients with metastatic melanoma. Curr. Opin. Immunol. 2009, 21, 233-240. [CrossRef] [PubMed]

8. Banchereau, J.; Palucka, K. Immunotherapy: Cancer vaccines on the move. Nat. Rev. Clin. Oncol. 2018, 15, 9-10. [CrossRef] [PubMed]

9. Garg, A.D.; Romano, E.; Rufo, N.; Agostinis, P. Immunogenic versus tolerogenic phagocytosis during anticancer therapy: Mechanisms and clinical translation. Cell Death Differ. 2016, 23, 938-951. [CrossRef] [PubMed]

10. Bekeschus, S.; Moritz, J.; Schmidt, A.; Wende, K. Redox regulation of leukocyte-derived microparticle release and protein content in response to cold physical plasma-derived oxidants. Clin. Plasma Med. 2017, 7-8, 24-35. [CrossRef]

11. Bekeschus, S.; Clemen, R.; Metelmann, H.-R. Potentiating anti-tumor immunity with physical plasma. Clin. Plasma Med. 2018, 12, 17-22. [CrossRef]

12. Bekeschus, S.; Seebauer, C.; Wende, K.; Schmidt, A. Physical plasma and leukocytes-Immune or reactive? Biol. Chem. 2019, 400, 63-75. [CrossRef] [PubMed]

13. Green, D.R.; Ferguson, T.; Zitvogel, L.; Kroemer, G. Immunogenic and tolerogenic cell death. Nat. Rev. Immunol. 2009, 9, 353-363. [CrossRef] [PubMed] 
14. Obeid, M.; Tesniere, A.; Ghiringhelli, F.; Fimia, G.M.; Apetoh, L.; Perfettini, J.L.; Castedo, M.; Mignot, G.; Panaretakis, T.; Casares, N.; et al. Calreticulin exposure dictates the immunogenicity of cancer cell death. Nat. Med. 2007, 13, 54-61. [CrossRef]

15. Ghiringhelli, F.; Apetoh, L.; Tesniere, A.; Aymeric, L.; Ma, Y.; Ortiz, C.; Vermaelen, K.; Panaretakis, T.; Mignot, G.; Ullrich, E. Activation of the nlrp3 inflammasome in dendritic cells induces il-1 $\beta$-dependent adaptive immunity against tumors. Nat. Med. 2009, 15, 1170. [CrossRef] [PubMed]

16. Kroemer, G.; Galluzzi, L.; Kepp, O.; Zitvogel, L. Immunogenic cell death in cancer therapy. Annu. Rev. Immunol. 2013, 31, 51-72. [CrossRef]

17. Nowak, A.K.; Lake, R.A.; Marzo, A.L.; Scott, B.; Heath, W.R.; Collins, E.J.; Frelinger, J.A.; Robinson, B.W. Induction of tumor cell apoptosis in vivo increases tumor antigen cross-presentation, cross-priming rather than cross-tolerizing host tumor-specific cd8 t cells. J. Immunol. 2003, 170, 4905-4913. [CrossRef] [PubMed]

18. Adkins, I.; Fucikova, J.; Garg, A.D.; Agostinis, P.; Spisek, R. Physical modalities inducing immunogenic tumor cell death for cancer immunotherapy. Oncoimmunology 2014, 3, e968434. [CrossRef] [PubMed]

19. Pasqual-Melo, G.; Gandhirajan, R.K.; Stoffels, I.; Bekeschus, S. Targeting malignant melanoma with physical plasmas. Clin. Plasma Med. 2018, 10, 1-8. [CrossRef]

20. Miller, V.; Lin, A.; Fridman, A. Why target immune cells for plasma treatment of cancer. Plasma Chem. Plasma Process. 2015, 36, 259-268. [CrossRef]

21. Barekzi, N.; Laroussi, M. Effects of low temperature plasmas on cancer cells. Plasma Process. Polym. 2013, 10, 1039-1050. [CrossRef]

22. Bekeschus, S.; Favia, P.; Robert, E.; von Woedtke, T. White paper on plasma for medicine and hygiene: Future in plasma health sciences. Plasma Process. Polym. 2019, 16, 1800033. [CrossRef]

23. Schmidt, A.; Bekeschus, S.; von Woedtke, T.; Hasse, S. Cell migration and adhesion of a human melanoma cell line is decreased by cold plasma treatment. Clin. Plasma Med. 2015, 3, 24-31. [CrossRef]

24. Arndt, S.; Wacker, E.; Li, Y.F.; Shimizu, T.; Thomas, H.M.; Morfill, G.E.; Karrer, S.; Zimmermann, J.L.; Bosserhoff, A.K. Cold atmospheric plasma, a new strategy to induce senescence in melanoma cells. Exp. Dermatol. 2013, 22, 284-289. [CrossRef] [PubMed]

25. Choi, B.B.R.; Choi, J.H.; Hong, J.W.; Song, K.W.; Lee, H.J.; Kim, U.K.; Kim, G.C. Selective killing of melanoma cells with non-thermal atmospheric pressure plasma and p-fak antibody conjugated gold nanoparticles. Int. J. Med. Sci. 2017, 14, 1101-1109. [CrossRef] [PubMed]

26. Binenbaum, Y.; Ben-David, G.; Gil, Z.; Slutsker, Y.Z.; Ryzhkov, M.A.; Felsteiner, J.; Krasik, Y.E.; Cohen, J.T. Cold atmospheric plasma, created at the tip of an elongated flexible capillary using low electric current, can slow the progression of melanoma. PLOS ONE 2017, 12, e0169457. [CrossRef] [PubMed]

27. Daeschlein, G.; Scholz, S.; Lutze, S.; Arnold, A.; von Podewils, S.; Kiefer, T.; Tueting, T.; Hardt, O.; Haase, H.; Grisk, O.; et al. Comparison between cold plasma, electrochemotherapy and combined therapy in a melanoma mouse model. Exp. Dermatol. 2013, 22, 582-586. [CrossRef] [PubMed]

28. Iida, M.; Omata, Y.; Nakano, C.; Yajima, I.; Tsuzuki, T.; Ishikawa, K.; Hori, M.; Kato, M. Decreased expression levels of cell cycle regulators and matrix metalloproteinases in melanoma from ret-transgenic mice by single irradiation of non-equilibrium atmospheric pressure plasmas. Int. J. Clin. Exp. Pathol. 2015, 8, 9326-9331.

29. Lorenzen, I.; Mullen, L.; Bekeschus, S.; Hanschmann, E.M. Redox regulation of inflammatory processes is enzymatically controlled. Oxid. Med. Cell. Longev. 2017, 2017, 8459402. [CrossRef]

30. Metelmann, H.R.; Seebauer, C.; Rutkowski, R.; Schuster, M.; Bekeschus, S.; Metelmann, P. Treating cancer with cold physical plasma: On the way to evidence-based medicine. Contrib. Plasma Phys. 2018, 58, 415-419. [CrossRef]

31. Gandhirajan, R.K.; Rodder, K.; Bodnar, Y.; Pasqual-Melo, G.; Emmert, S.; Griguer, C.E.; Weltmann, K.D.; Bekeschus, S. Cytochrome c oxidase inhibition and cold plasma-derived oxidants synergize in melanoma cell death induction. Sci. Rep. 2018, 8, 12734. [CrossRef]

32. Sagwal, S.K.; Pasqual-Melo, G.; Bodnar, Y.; Gandhirajan, R.K.; Bekeschus, S. Combination of chemotherapy and physical plasma elicits melanoma cell death via upregulation of slc22a16. Cell Death Dis. 2018, 9, 1179. [CrossRef] [PubMed]

33. Masur, K.; von Behr, M.; Bekeschus, S.; Weltmann, K.D.; Hackbarth, C.; Heidecke, C.D.; von Bernstorff, W.; von Woedtke, T.; Partecke, L.I. Synergistic inhibition of tumor cell proliferation by cold plasma and gemcitabine. Plasma Process. Polym. 2015, 12, 1377-1382. [CrossRef] 
34. Bekeschus, S.; Rodder, K.; Fregin, B.; Otto, O.; Lippert, M.; Weltmann, K.D.; Wende, K.; Schmidt, A.; Gandhirajan, R.K. Toxicity and immunogenicity in murine melanoma following exposure to physical plasma-derived oxidants. Oxid. Med. Cell. Longev. 2017, 2017, 4396467. [CrossRef] [PubMed]

35. Lin, A.; Truong, B.; Patel, S.; Kaushik, N.; Choi, E.H.; Fridman, G.; Fridman, A.; Miller, V. Nanosecond-pulsed dbd plasma-generated reactive oxygen species trigger immunogenic cell death in a549 lung carcinoma cells through intracellular oxidative stress. Int. J. Mol. Sci. 2017, 18, 966. [CrossRef] [PubMed]

36. Bekeschus, S.; Schmidt, A.; Niessner, F.; Gerling, T.; Weltmann, K.D.; Wende, K. Basic research in plasma medicine-A throughput approach from liquids to cells. J. Vis. Exp. 2017, e56331. [CrossRef] [PubMed]

37. Bekeschus, S.; Schmidt, A.; Kramer, A.; Metelmann, H.R.; Adler, F.; von Woedtke, T.; Niessner, F.; Weltmann, K.D.; Wende, K. High throughput image cytometry micronucleus assay to investigate the presence or absence of mutagenic effects of cold physical plasma. Environ. Mol. Mutagen. 2018, 59, 268-277. [CrossRef] [PubMed]

38. Winter, J.; Wende, K.; Masur, K.; Iseni, S.; Dunnbier, M.; Hammer, M.U.; Tresp, H.; Weltmann, K.D.; Reuter, S. Feed gas humidity: A vital parameter affecting a cold atmospheric-pressure plasma jet and plasma-treated human skin cells. J. Phys. D Appl. Phys. 2013, 46, 295401. [CrossRef]

39. Liang, C.C.; Park, A.Y.; Guan, J.L. In vitro scratch assay: A convenient and inexpensive method for analysis of cell migration in vitro. Nat. Protoc. 2007, 2, 329-333. [CrossRef]

40. Lackmann, J.W.; Wende, K.; Verlackt, C.; Golda, J.; Volzke, J.; Kogelheide, F.; Held, J.; Bekeschus, S.; Bogaerts, A.; Schulz-von der Gathen, V.; et al. Chemical fingerprints of cold physical plasmas-An experimental and computational study using cysteine as tracer compound. Sci. Rep. 2018, 8, 7736. [CrossRef]

41. England, H.; Summersgill, H.R.; Edye, M.E.; Rothwell, N.J.; Brough, D. Release of interleukin- $1 \alpha$ or interleukin-1 $\beta$ depends on mechanism of cell death. J. Biol. Chem. 2014, 289, 15942-15950. [CrossRef]

42. Martinon, F.; Pétrilli, V.; Mayor, A.; Tardivel, A.; Tschopp, J. Gout-associated uric acid crystals activate the nalp3 inflammasome. Nature 2006, 440, 237. [CrossRef] [PubMed]

43. Nakae, S.; Asano, M.; Horai, R.; Iwakura, Y. Interleukin-1 $\beta$, but not interleukin- $1 \alpha$, is required for t-cell-dependent antibody production. Immunology 2001, 104, 402-409. [CrossRef] [PubMed]

44. Ben-Sasson, S.Z.; Hu-Li, J.; Quiel, J.; Cauchetaux, S.; Ratner, M.; Shapira, I.; Dinarello, C.A.; Paul, W.E. Il-1 acts directly on cd $4 \mathrm{t}$ cells to enhance their antigen-driven expansion and differentiation. Proc. Natl. Acad. Sci. USA 2009, 106, 7119-7124. [CrossRef] [PubMed]

45. O'Sullivan, B.J.; Thomas, H.E.; Pai, S.; Santamaria, P.; Iwakura, Y.; Steptoe, R.J.; Kay, T.W.; Thomas, R. Il-1 $\beta$ breaks tolerance through expansion of cd25+ effector t cells. J. Immunol. 2006, 176, 7278-7287. [CrossRef] [PubMed]

46. Kapas, L.; Hong, L.; Cady, A.B.; Opp, M.R.; Postlethwaite, A.E.; Seyer, J.M.; Krueger, J.M. Somnogenic, pyrogenic, and anorectic activities of tumor necrosis factor-alpha and tnf-alpha fragments. Am. J. Physiol. 1992, 263, R708-R715. [CrossRef] [PubMed]

47. Bystry, R.S.; Aluvihare, V.; Welch, K.A.; Kallikourdis, M.; Betz, A.G. B cells and professional apcs recruit regulatory t cells via ccl4. Nat. Immunol. 2001, 2, 1126-1132. [CrossRef] [PubMed]

48. Bezu, L.; Gomes-de-Silva, L.C.; Dewitte, H.; Breckpot, K.; Fucikova, J.; Spisek, R.; Galluzzi, L.; Kepp, O.; Kroemer, G. Combinatorial strategies for the induction of immunogenic cell death. Front. Immunol. 2015, 6, 187. [CrossRef]

49. Mizuno, K.; Shirakawa, Y.; Sakamoto, T.; Ishizaki, H.; Nishijima, Y.; Ono, R. Plasma-induced suppression of recurrent and reinoculated melanoma tumors in mice. IEEE Trans. Radiat. Plasma Med. Sci. 2018, 2, 353-359. [CrossRef]

50. Mizuno, K.; Yonetamari, K.; Shirakawa, Y.; Akiyama, T.; Ono, R. Anti-tumor immune response induced by nanosecond pulsed streamer discharge in mice. J. Phys. D Appl. Phys. 2017, 50, 12LT01. [CrossRef]

51. Bekeschus, S.; Kolata, J.; Muller, A.; Kramer, A.; Weltmann, K.-D.; Broker, B.; Masur, K. Differential viability of eight human blood mononuclear cell subpopulations after plasma treatment. Plasma Med. 2013, 3, 1-13. [CrossRef]

52. Bundscherer, L.; Bekeschus, S.; Tresp, H.; Hasse, S.; Reuter, S.; Weltmann, K.-D.; Lindequist, U.; Masur, K. Viability of human blood leukocytes compared with their respective cell lines after plasma treatment. Plasma Med. 2013, 3, 71-80. [CrossRef] 
53. Bekeschus, S.; Rödder, K.; Schmidt, A.; Stope, M.B.; von Woedtke, T.; Miller, V.; Fridman, A.; Weltmann, K.-D.; Masur, K.; Metelmann, H.-R.; et al. Cold physical plasma selects for specific thelper cell subsets with distinct cells surface markers in a caspase-dependent and nf-kb-independent manner. Plasma Process. Polym. 2016, 13, 1144-1150. [CrossRef]

54. Saito, Y.; Nishio, K.; Ogawa, Y.; Kimata, J.; Kinumi, T.; Yoshida, Y.; Noguchi, N.; Niki, E. Turning point in apoptosis/necrosis induced by hydrogen peroxide. Free Radic. Res. 2006, 40, 619-630. [CrossRef] [PubMed]

55. Reth, M. Hydrogen peroxide as second messenger in lymphocyte activation. Nat. Immunol. 2002, 3, 1129. [CrossRef] [PubMed]

56. Premack, B.A.; Gardner, P. Signal transduction by t-cell receptors: Mobilization of ca and regulation of ca-dependent effector molecules. Am. J. Physiol.-Cell Physiol. 1992, 263, C1119-C1140. [CrossRef] [PubMed]

57. Lewis, R.S.; Cahalan, M.D. Potassium and calcium channels in lymphocytes. Annu. Rev. Immunol. 1995, 13, 623-653. [CrossRef] [PubMed]

58. Goldsmith, M.A.; Weiss, A. Early signal transduction by the antigen receptor without commitment to $t$ cell activation. Science 1988, 240, 1029-1031. [CrossRef] [PubMed]

59. Atherfold, P.; Norris, M.; Robinson, P.; Gelfand, E.; Franklin, R. Calcium-induced erk activation in human $\mathrm{t}$ lymphocytes. Mol. Immunol. 1999, 36, 543-549. [CrossRef]

60. Franklin, R.A.; Atherfold, P.A.; McCubrey, J.A. Calcium-induced erk activation in human tymphocytes occurs via p56lck and cam-kinase. Mol. Immunol. 2000, 37, 675-683. [CrossRef]

61. Bekeschus, S.; Masur, K.; Kolata, J.; Wende, K.; Schmidt, A.; Bundscherer, L.; Barton, A.; Kramer, A.; Broker, B.; Weltmann, K.D. Human mononuclear cell survival and proliferation is modulated by cold atmospheric plasma jet. Plasma Process. Polym. 2013, 10, 706-713. [CrossRef]

62. Van der Linde, J.; Liedtke, K.R.; Matthes, R.; Kramer, A.; Heidecke, C.-D.; Partecke, L.I. Repeated cold atmospheric plasma application to intact skin does not cause sensitization in a standardized murine model. Plasma Med. 2017, 7, 383-393. [CrossRef]

63. Brune, B.; Dehne, N.; Grossmann, N.; Jung, M.; Namgaladze, D.; Schmid, T.; von Knethen, A.; Weigert, A. Redox control of inflammation in macrophages. Antioxid. Redox Signal. 2013, 19, 595-637. [CrossRef] [PubMed]

64. Partida-Sanchez, S.; Iribarren, P.; Moreno-Garcia, M.E.; Gao, J.L.; Murphy, P.M.; Oppenheimer, N.; Wang, J.M.; Lund, F.E. Chemotaxis and calcium responses of phagocytes to formyl peptide receptor ligands is differentially regulated by cyclic adp ribose. J. Immunol. 2004, 172, 1896-1906. [CrossRef] [PubMed]

65. Notter, M.; Schirrmacher, V. Tumor-specific t-cell clones recognize different protein determinants of autologous human malignant melanoma cells. Int. J. Cancer 1990, 45, 834-841. [CrossRef]

66. Anichini, A.; Mazzocchi, A.; Fossati, G.; Parmiani, G. Cytotoxic t lymphocyte clones from peripheral blood and from tumor site detect intratumor heterogeneity of melanoma cells. Analysis of specificity and mechanisms of interaction. J. Immunol. 1989, 142, 3692-3701. [PubMed]

67. Wolfel, T.; Hauer, M.; Klehmann, E.; Brichard, V.; Ackermann, B.; Knuth, A.; Boon, T.; Meyer Zum Buschenfelde, K.H. Analysis of antigens recognized on human melanoma cells by a2-restricted cytolytic $t$ lymphocytes (ctl). Int. J. Cancer 1993, 55, 237-244. [CrossRef] [PubMed]

68. Shahinian, A.; Pfeffer, K.; Lee, K.P.; Kundig, T.M.; Kishihara, K.; Wakeham, A.; Kawai, K.; Ohashi, P.S.; Thompson, C.B.; Mak, T.W. Differential t cell costimulatory requirements in cd28-deficient mice. Science 1993, 261, 609-612. [CrossRef] [PubMed]

69. Linsley, P.S.; Ledbetter, J.A. The role of the $\mathrm{cd} 28$ receptor during $\mathrm{t}$ cell responses to antigen. Annu. Rev. Immunol. 1993, 11, 191-212. [CrossRef]

70. Vella, A.T.; Mitchell, T.; Groth, B.; Linsley, P.S.; Green, J.M.; Thompson, C.B.; Kappler, J.W.; Marrack, P. Cd28 engagement and proinflammatory cytokines contribute to $t$ cell expansion and long-term survival in vivo. J. Immunol. 1997, 158, 4714-4720. [PubMed]

71. Sperling, A.I.; Auger, J.A.; Ehst, B.D.; Rulifson, I.C.; Thompson, C.B.; Bluestone, J.A. Cd28/b7 interactions deliver a unique signal to naive $t$ cells that regulates cell survival but not early proliferation. J. Immunol. 1996, 157, 3909-3917. [PubMed]

72. Mueller, D.L.; Seiffert, S.; Fang, W.; Behrens, T.W. Differential regulation of bcl-2 and bcl-x by cd3, cd28, and the il-2 receptor in cloned cd4+ helper $t$ cells. A model for the long-term survival of memory cells. J. Immunol. 1996, 156, 1764-1771. [PubMed] 
73. Arosa, F.A. $\mathrm{Cd} 8+\mathrm{cd} 28-\mathrm{t}$ cells: Certainties and uncertainties of a prevalent human $\mathrm{t}$-cell subset. Immunol. Cell Biol. 2002, 80, 1-13. [CrossRef] [PubMed]

74. Berner, B.; Akca, D.; Jung, T.; Muller, G.A.; Reuss-Borst, M.A. Analysis of th1 and th2 cytokines expressing $\mathrm{cd} 4+$ and cd8+ $\mathrm{t}$ cells in rheumatoid arthritis by flow cytometry. J. Rheumatol. 2000, 27, 1128-1135. [PubMed]

75. Morelli, A.E. Cytokine production by mouse myeloid dendritic cells in relation to differentiation and terminal maturation induced by lipopolysaccharide or cd40 ligation. Blood 2001, 98, 1512-1523. [CrossRef] [PubMed]

76. Fleischer, J.; Soeth, E.; Reiling, N.; GRAGE-GRIEBENOW, E.; FLAD, H.D.; Ernst, M. Differential expression and function of cd80 (b7-1) and cd86 (b7-2) on human peripheral blood monocytes. Immunology 1996, 89, 592-598. [CrossRef] [PubMed]

77. Girndt, M.; Sester, M.; Sester, U.; Kaul, H.; Köhler, H. Defective expression of b7-2 (cd86) on monocytes of dialysis patients correlates to the uremia-associated immune defect. Kidney Int. 2001, 59, 1382-1389. [CrossRef] [PubMed]

78. Maurer, D.; Fiebiger, E.; Reininger, B.; Wolff-Winiski, B.; Jouvin, M.-H.; Kilgus, O.; Kinet, J.-P.; Stingl, G. Expression of functional high affinity immunoglobulin e receptors (fc epsilon ri) on monocytes of atopic individuals. J. Exp. Med. 1994, 179, 745-750. [CrossRef] [PubMed]

79. Melewicz, F.; Zeiger, R.; Mellon, M.; O'Connor, R.; Spiegelberg, H. Increased ige-dependent cytotoxicity by blood mononuclear cells of allergic patients. Clin. Exp. Immunol. 1981, 43, 526.

80. Nucera, S.; Biziato, D.; De Palma, M. The interplay between macrophages and angiogenesis in development, tissue injury and regeneration. Int. J. Dev. Biol. 2011, 55, 495-503. [CrossRef]

81. Italiani, P.; Boraschi, D. From monocytes to $\mathrm{m} 1 / \mathrm{m} 2$ macrophages: Phenotypical vs. Functional differentiation. Front. Immunol. 2014, 5, 514. [CrossRef] [PubMed]

82. Bekeschus, S.; Freund, E.; Wende, K.; Gandhirajan, R.; Schmidt, A. Hmox1 upregulation is a mutual marker in human tumor cells exposed to physical plasma-derived oxidants. Antioxidants 2018, 7, 151. [CrossRef] [PubMed]

83. Bekeschus, S.; Kading, A.; Schroder, T.; Wende, K.; Hackbarth, C.; Liedtke, K.R.; van der Linde, J.; von Woedtke, T.; Heidecke, C.D.; Partecke, L.I. Cold physical plasma treated buffered saline solution as effective agent against pancreatic cancer cells. Anticancer Agents Med. Chem. 2018, 18, 824-831. [CrossRef] [PubMed]

84. Bekeschus, S.; Lin, A.; Fridman, A.; Wende, K.; Weltmann, K.D.; Miller, V. A comparison of floating-electrode $\mathrm{dbd}$ and kinpen jet: Plasma parameters to achieve similar growth reduction in colon cancer cells under standardized conditions. Plasma Chem. Plasma Process. 2018, 38, 1-12. [CrossRef]

85. Bekeschus, S.; Mueller, A.; Miller, V.; Gaipl, U.; Weltmann, K.-D. Physical plasma elicits immunogenic cancer cell death and mitochondrial singlet oxygen. IEEE Trans. Radiat. Plasma Med. Sci. 2018, 2, 138-146. [CrossRef]

86. Bekeschus, S.; Wende, K.; Hefny, M.M.; Rodder, K.; Jablonowski, H.; Schmidt, A.; Woedtke, T.V.; Weltmann, K.D.; Benedikt, J. Oxygen atoms are critical in rendering thp-1 leukaemia cells susceptible to cold physical plasma-induced apoptosis. Sci. Rep. 2017, 7, 2791. [CrossRef] [PubMed]

87. Bekeschus, S.; Wulf, C.; Freund, E.; Koensgen, D.; Mustea, A.; Weltmann, K.-D.; Stope, M. Plasma treatment of ovarian cancer cells mitigates their immuno-modulatory products active on thp-1 monocytes. Plasma 2018, 1, 201-217. [CrossRef]

88. Adachi, T.; Tanaka, H.; Nonomura, S.; Hara, H.; Kondo, S.; Hori, M. Plasma-activated medium induces a549 cell injury via a spiral apoptotic cascade involving the mitochondrial-nuclear network. Free Radic. Biol. Med. 2015, 79, 28-44. [CrossRef]

89. Ahn, H.J.; Kim, K.I.; Hoan, N.N.; Kim, C.H.; Moon, E.; Choi, K.S.; Yang, S.S.; Lee, J.S. Targeting cancer cells with reactive oxygen and nitrogen species generated by atmospheric-pressure air plasma. PLoS ONE 2014, 9, e86173. [CrossRef]

90. Akhlaghi, M.; Rajaei, H.; Mashayekh, A.S.; Shafiae, M.; Mahdikia, H.; Khani, M.; Hassan, Z.M.; Shokri, B. Determination of the optimum conditions for lung cancer cells treatment using cold atmospheric plasma. Phys. Plasmas 2016, 23. [CrossRef]

91. Aryal, S.; Bisht, G. New paradigm for a targeted cancer therapeutic approach: A short review on potential synergy of gold nanoparticles and cold atmospheric plasma. Biomedicines 2017, 5, 38. [CrossRef]

92. Boehm, D.; Curtin, J.; Cullen, P.J.; Bourke, P. Hydrogen peroxide and beyond-the potential of high-voltage plasma-activated liquids against cancerous cells. Anticancer Agents Med. Chem. 2018, 18, 815-823. [CrossRef] [PubMed] 
93. Chang, J.W.; Kang, S.U.; Shin, Y.S.; Kim, K.I.; Seo, S.J.; Yang, S.S.; Lee, J.S.; Moon, E.; Lee, K.; Kim, C.H. Non-thermal atmospheric pressure plasma inhibits thyroid papillary cancer cell invasion via cytoskeletal modulation, altered mmp-2/-9/upa activity. PLoS ONE 2014, 9, e92198. [CrossRef] [PubMed]

94. Chang, J.W.; Kang, S.U.; Shin, Y.S.; Kim, K.I.; Seo, S.J.; Yang, S.S.; Lee, J.-S.; Moon, E.; Baek, S.J.; Lee, K. Non-thermal atmospheric pressure plasma induces apoptosis in oral cavity squamous cell carcinoma: Involvement of DNA-damage-triggering sub-g $\mathrm{g}_{1}$ arrest via the atm/p53 pathway. Arch. Biochem. Biophys. 2014, 545, 133-140. [CrossRef]

95. Chen, Z.; Lin, L.; Cheng, X.; Gjika, E.; Keidar, M. Treatment of gastric cancer cells with nonthermal atmospheric plasma generated in water. Biointerphases 2016, 11, 031010. [CrossRef] [PubMed]

96. Chen, Z.; Simonyan, H.; Cheng, X.; Gjika, E.; Lin, L.; Canady, J.; Sherman, J.H.; Young, C.; Keidar, M. A novel micro cold atmospheric plasma device for glioblastoma both in vitro and in vivo. Cancers 2017, 9, 61. [CrossRef] [PubMed]

97. Chen, Z.T.; Lin, L.; Cheng, X.Q.; Gjika, E.; Keidar, M. Effects of cold atmospheric plasma generated in deionized water in cell cancer therapy. Plasma Process. Polym. 2016, 13, 1151-1156. [CrossRef]

98. Cheng, X.; Sherman, J.; Murphy, W.; Ratovitski, E.; Canady, J.; Keidar, M. The effect of tuning cold plasma composition on glioblastoma cell viability. PLoS ONE 2014, 9, e98652. [CrossRef]

99. Kumar, N.; Attri, P.; Dewilde, S.; Bogaerts, A. Inactivation of human pancreatic ductal adenocarcinoma with atmospheric plasma treated media and water: A comparative study. J. Phys. D Appl. Phys. 2018, 51. [CrossRef]

100. Kumar, N.; Park, J.H.; Jeon, S.N.; Park, B.S.; Choi, E.H.; Attri, P. The action of microsecond-pulsed plasma-activated media on the inactivation of human lung cancer cells. J. Phys. D Appl. Phys. 2016, 49. [CrossRef]

101. Schmidt, A.; Bekeschus, S.; Jarick, K.; Hasse, S.; von Woedtke, T.; Wende, K. Cold physical plasma modulates p53 and mitogen-activated protein kinase signaling in keratinocytes. Oxid. Med. Cell. Longev. 2019, 2019, 1-16. [CrossRef]

(C) 2019 by the authors. Licensee MDPI, Basel, Switzerland. This article is an open access article distributed under the terms and conditions of the Creative Commons Attribution (CC BY) license (http:/ / creativecommons.org/licenses/by/4.0/). 